DOI: https://doi.org/10.47405/mjssh.v6i9.1012

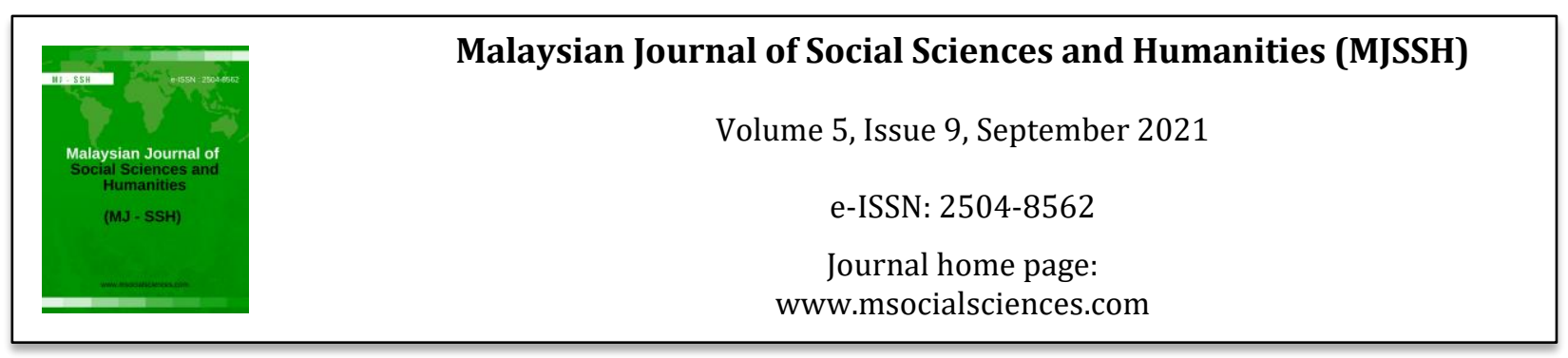

\title{
Perkaitan Antara Sokongan Sosial Keluarga dengan Kemurungan dalam kalangan Anggota Polis Jabatan Siasatan Jenayah, Selangor
}

\author{
Mohammad Arif Bin Johari'1, Sa'odah Binti Ahmad ${ }^{1}$, Zanariah Binti Ismail ${ }^{1}$ \\ 1Jabatan Pembangunan Manusia dan Pengajian Keluarga, Fakulti Ekologi Manusia, Universiti Putra Malaysia (UPM) \\ Correspondence: Mohammad Arif Bin Johari (mohammad arif@upm.edu.my)
}

\begin{abstract}
Abstrak
Kajian tinjauan ini bertujuan untuk mengenal pasti sama ada terdapat perkaitan antara sokongan sosial keluarga dengan kemurungan dalam kalangan anggota Polis Jabatan Siasatan Jenayah di Selangor. Kajian ini melibatkan 336 anggota polis yang telah dipilih secara rawak sebagai responden dalam kajian ini. Borang soal selidik yang diisi sendiri oleh responden telah digunakan untuk mengumpul data kajian. Skala The Depression Anxiety Stress Scale (DASS-21) oleh Lovibond, \&, Lovibond (1995) telah digunakan untuk mengukur tahap kemurungan. Sokongan sosial keluarga (emosi dan instrumental) pula telah diukur dengan menggunakan Family Support Inventory for Workers oleh King, Mattimore, King dan Adams (1995). Hasil kajian menunjukkan terdapat perkaitan yang signifikan antara sokongan emosi $\left(\mathrm{r}=0.296^{* *}, \mathrm{p} \leq 0.05\right)$ dan sokongan instrumental $\left(\mathrm{r}=0.343^{* *}, \mathrm{p} \leq 0.05\right)$ dengan kemurungan responden. Kajian ini juga mendapati sokongan instrumental $(\beta=0.363)$ merupakan faktor peramal yang paling mempengaruhi kemurungan responden. Sehubungan itu, sebarang program intervensi berkaitan kemurungan dalam kalangan anggota polis haruslah memberi penekanan kepada aspek sokongan sosial keluarga kerana kajian ini telah membuktikan bahawa sokongan sosial keluarga adalah peramal kepada kemurungan.
\end{abstract}

Kata kunci: sokongan sosial keluarga, kemurungan, anggota polis

\section{The Relationship Between Family Social Support and Depression Among the Police Officers of The Crime Investigation Department in Selangor}

\begin{abstract}
This study was conducted to identify the relationship between family social support with depression among the police officers of the Crime Investigation Department in Selangor. This study involved 336 police officers who were selected randomly as respondents for the study. A self-administered questionnaire was used to collect the data of this study. The Depression Anxiety Stress Scale (DASS21) by Lovibond \& Lovibond (1995) was used to measure the level of depression among the respondents. Meanwhile, Family Support Inventory for Workers (FSIW) by King, Mattimore, King \& Adams (1995) was used to measure the respondents' family social support. The results showed that there was a significant correlation between family emotional support $\left(r=0.296^{* *}, p \leq 0.05\right)$ and family instrumental support $\left(\mathrm{r}=0.343^{* *}, \mathrm{p} \leq 0.05\right)$ with depression. The study also found that family instrumental support $(\beta=0.363)$ was the strongest predictor of the respondents' depression. Thus, any intervention program related to depression of the police officers must focus on the aspect of family social support because this study had proven that family social support was the predictor of depression among police officer.
\end{abstract}


Keywords: family social support, depression, police officer

\section{Pengenalan}

Isu kesihatan mental dalam kalangan anggota polis adalah isu global yang serius. Kemurungan merujuk kepada gangguan mental yang mengakibatkan perasaan tertekan, kehilangan minat dan keseronokan, kurang tenaga, rendah harga diri, rasa bersalah, masalah tidur dan kurang selera makan (World Health Organization, 2012). Kajian oleh Weiss et al. (1999) menunjukkan sebanyak 25\% anggota polis di Amerika Syarikat mempunyai pengalaman mencederakan atau membunuh tanpa sengaja seseorang individu semasa menjalankan tugas akibat kemurungan. Juga didapati, 10\% anggota polis terlibat dengan tindakan membunuh atau mencederakan orang lain ketika menjalankan tugas dalam tempoh 3 tahun pertama perkhidmatan mereka (Komaorvskaya et al., 2011). Kedua-dua kajian ini mendapati tindakan membunuh atau mencederakan orang lain mempunyai perkaitan yang signifikan dengan gejala Post-Traumatic Stress Disorder (PTSD) yang berkaitan dengan kemurungan. Kesan kemurungan terhadap anggota polis juga dapat dilihat dengan perlakuan membunuh diri dalam kalangan anggota polis (World Health Organization, 2012).

Polis Diraja Malaysia (PDRM) merupakan sebuah organisasi penguatkuasaan undang-undang yang utama di Malaysia (Subri et al., 2011). Tugas utama anggota polis adalah melindungi nyawa dan harta orang awam serta memerangi dan mencegah jenayah dalam masyarakat. Anggota polis bertanggungjawab mempertahankan keamanan dan ketenteraman awam yang tidak terhad kepada ketenteraman yang berkaitan manusia malah bersangkutan juga dengan bencana alam. PDRM adalah agensi yang pertama dikehendaki bertindak balas sekiranya berlaku sesuatu ancaman dari dalam negara (Salmah, 2009). Berdasarkan peranan ini, anggota polis terdedah kepada risiko kemurungan akibat pelbagai faktor seperti gaya hidup moden, tuntutan dan tekanan kerja yang semakin meningkat serta perubahan dalam persekitaran psikososial dan fizikal. Contohnya, akibat penularan pandemik Covid-19 kini, anggota polis menanggung beban kerja yang lebih kerana terpaksa membuat sekatan jalan raya ekoran daripada perintah kawalan pergerakan yang dilaksanakan kerajaan.

Statistik oleh Tinjauan Kesihatan dan Morbiditi Kebangsaan (NHMS, 2019) telah menjangka peningkatan dalam kadar penyakit mental dan ia menjadi masalah kesihatan kedua terbesar yang membahayakan rakyat Malaysia selepas penyakit jantung. Pada tahun 2020 prevalens kemurungan dalam kalangan orang dewasa di peringkat nasional adalah $2.3 \%$ iaitu seramai setengah juta orang dan terdapat peningkatan $20 \%$ kes bunuh diri akibat kemurungan direkodkan berbanding dengan jumlah yang direkodkan pada tahun 2019 (NHMS, 2020). Selain daripada membunuh diri, kesan kemurungan yang lain adalah peningkatan kebimbangan, tekanan somatik, gejala tekanan pasca-traumatik, keletihan, sakit belakang kronik, penyalahgunaan alkohol, dan kelakuan yang agresif (Gershon dan Lin, 2002). Jelas dilihat, kemurungan adalah membahayakan dan menyebabkan ketidakupayaan yang boleh menyumbang kepada tindakan agresif, tidak terkawal dan yang lebih ekstrem lagi sehingga membunuh diri sendiri. Merujuk kepada Teori Ekologi Keluarga (Bubolz \& Sontag, 1993), individu mempengaruhi dan dipengaruhi oleh persekitarannya. Maka, pengalaman atau masalah kemurungan individu akan turut memberi kesan kepada ahli keluarga yang lain.

Sokongan sosial keluarga merupakan faktor pelindung yang dapat mengurangkan potensi kemurungan dalam kalangan anggota polis. Sokongan sosial keluarga adalah bantuan yang diberikan oleh ahli keluarga yang boleh meningkatkan keselesaan fizikal dan psikologi anggota polis yang menghadapi situasi tertekan (Chesla et al., 2004). Cohen (2015) menjelaskan bahawa sokongan sosial keluarga bukan sahaja berfungsi secara efektif dalam menurunkan tahap tekanan kerja dan kemurungan, tetapi juga mempunyai kesan positif dalam meningkatkan harga diri. Kajian Sheeber et al. (2016) menunjukkan sokongan sosial adalah faktor peramal yang utama kepada kemurungan dalam kalangan anggota polis. Antara bentuk sokongan sosial keluarga ialah sentiasa bersikap positif, memberi dorongan dan nasihat serta berkongsi kerja rumah untuk mengurangkan bebanan dan tekanan yang dihadapi oleh anggota polis. 
Masih kurang kajian mengenai perkaitan antara sokongan keluarga dengan kemurungan dalam kalangan anggota polis di Malaysia. Kajian lepas lebih banyak memfokuskan kepada pengaruh konflik kerja-keluarga, kesan tuntutan kerja, sokongan sosial dan sokongan penyelia kepada anggota polis (Saleh et al., 2015). Justeru, kajian yang mengukur perkaitan antara sokongan keluarga dengan kemurungan dalam kalangan anggota polis ini dijalankan bagi mengisi jurang kajian tersebut. Dapatan kajian ini berpotensi menyumbang kepada pengkayaan ilmu dalam bidang di samping boleh menjadi rujukan serta asas kepada sebarang langkah atau program intervensi yang boleh diambil oleh pihak berautoriti khususnya organisasi PDRM sendiri bagi memastikan penyakit mental seperti kemurungan dalam kalangan anggota polis diberi perhatian dan ditangani sewajarnya.

\section{Objektif Kajian}

Kajian ini mempunyai tiga objektif iaitu:

i. Untuk memerihalkan latar belakang anggota polis (jantina, umur, taraf perkahwinan, bilangan anak, dan jumlah tahun pendidikan), sokongan keluarga dan kemurungan dalam kalangan anggota polis.

ii. Untuk menentukan perkaitan sokongan sosial keluarga (sokongan emosi dan sokongan instrumental) dengan kemurungan dalam kalangan anggota polis.

iii. Untuk menentukan faktor peramal unik yang mempengaruhi kemurungan dalam kalangan anggota polis.

\section{Sorotan Literatur}

\section{Kemurungan dalam kalangan anggota polis}

Kemurungan merupakan kecelaruan atau penyakit mental biasa yang dihidapi oleh lebih 264 juta penduduk dunia (Pertubuhan Kesihatan Sedunia, 2020). Antara contoh gejala seperti kesedihan berpanjangan, kemarahan, hilang minat atau keseronokan dalam aktiviti yang diminati sebelum ini (Lawson et al., 2012). Sebanyak 266 kes membunuh diri telah dilaporkan pada tahun 2020 (PDRM, 2020). Antara punca bunuh diri adalah pandemik Covid-19 yang menyebabkan tekanan/kemurungan akibat bebanan hutang bertambah (25\%), masalah keluarga (24\%), masalah rumah tangga (23\%), masalah cinta (15\%) dan punca lain (13\%). Kajian oleh Queiros et al. (2020) menunjukkan kerjaya sebagai anggota polis yang penuh dengan tekanan memberi kesan negatif kepada kesihatan mental anggota polis dan menjejaskan prestasi kerja serta interaksi sesama manusia. Pekerjaan polis disenaraikan sebagai tiga kerjaya paling atas dalam senarai Pengawasan Tekanan Pekerjaan dan Penyakit Mental (SOSMI) di peringkat global (Purba \& Demou, 2019).

Anggota polis adalah pihak pertama yang biasanya berada di tempat kejadian jenayah. Mereka adalah golongan yang memberi bantuan segera kepada masyarakat dalam situasi kecemasan atau bahaya. Oleh yang demikian, tanggungjawab berat ini mendedahkan anggota polis kepada risiko tekanan fizikal dan kesihatan mental. Risiko yang dihadapi termasuklah cedera parah atau terbunuh, serangan pengganas, sumber kemanusiaan dan material yang terhad, kecaman daripada orang awam dan masyarakat, kurang persefahaman daripada rakan dan keluarga yang boleh menjejaskan kesejahteraan psikologi dan menyebabkan keletihan fizikal kepada mereka (Queiros et al, 2020; Purba \& Demou, 2019; Magnavita et al. 2018; Wang, 2010). Kajian Husain dan Faize (2018) ke atas 315 anggota polis di Peshawar, Abbottabad dan Mardan (dalam Wilayah Khyber Pukhtoonkhwa, yang terkenal dengan aktiviti pengganas) di Pakistan mendapati tahap kemurungan dalam kalangan anggota polis adalah tinggi disebabkan oleh peningkatan bebanan kerja dan faktor pemindahan terutamanya ke balai polis yang sensitif dan mempunyai risiko kejadian jenayah yang tinggi.

Penglibatan anggota polis dalam mencegah jenayah boleh mendorong kepada kemurungan. Anggota polis berhadapan dengan kes jenayah yang akan meninggalkan impak seperti trauma dan ini 
mengganggu mereka dalam menjalankan tugas seharian. Pendedahan secara kerap kepada situasi yang melibatkan kemalangan maut, penderaan, keganasan ditambah pula dengan waktu kerja yang panjang, tuntutan kerja dan konflik kerja keluarga yang tinggi boleh menyebabkan anggota polis berasa hilang harapan, mengalami tahap tekanan tinggi dan seterusnya mengalami pelbagai isu kesihatan mental seperti kemurungan (Husain \& Faize, 2018). Dalam konteks Malaysia, kajian oleh Pusat Perubatan Universiti Kebangsaan Malaysia yang dijalankan antara tahun 2007 hingga 2009 mendapati 53.7\% anggota polis daripada 453 sampel kajian di enam balai polis di Wilayah Persekutuan mengalami tekanan di tempat kerja. Malahan, polis berada di tangga teratas dan mengatasi kerjaya beruniform lain seperti bomba (47.3\%), guru (45.8\%), jururawat (42.3\%) dan doktor (40.7\%) (Hasmizal, 2007). Tinjauan literatur, mendapati wujud jurang dalam kajian berkaitan dengan kemurungan dalam kalangan anggota polis di Malaysia. Kajian sedia ada hanya memfokuskan kepada faktor atau punca tekanan, kesan tekanan kerja terhadap kepuasan dan komitmen kerja serta kecerdasan emosi (Zaidi \& Raop, 2017) Ringkasnya, tumpuan hanya kepada faktor yang mempengaruhi kesejahteraan psikologi anggota polis secara umum dan tidak mengambil kira bagaimana faktor tersebut boleh menyumbang kepada penyakit mental khususnya kemurungan.

\section{Sokongan sosial keluarga}

Sokongan sosial keluarga merupakan aspek penting dalam membentuk hubungan kekeluargaan dan kesejahteraan psikologi yang kukuh. Button (2008) mendefinisikan sokongan sosial keluarga sebagai gabungan hubungan sosial, interaksi emosi dan tingkah laku dan persepsi individu tentang sikap ketersediaan pelbagai jenis sokongan. Chesla (2008) berpendapat bahawa sokongan sosial keluarga melibatkan jaringan keluarga dan rakan-rakan yang boleh dirujuk apabila seseorang individu menghadapi masalah. Selain itu, sokongan sosial keluarga ini juga merupakan sokongan atau bantuan yang diberikan oleh ahli keluarga dan rakan-rakan bagi meningkatkan keselesaan fizikal dan psikologi individu yang menghadapi situasi yang tertekan.

Sokongan sosial keluarga didapati memberi kesan positif kepada anggota polis yang mengalami penyakit mental (Komjakraphan et al., 2009). Sokongan sosial keluarga menyediakan maklumat yang menyebabkan individu percaya bahawa keperluan asas sosial mereka dipenuhi melalui interaksi dengan ahli keluarga. Sokongan sosial keluarga boleh dikategorikan kepada aspek struktur dan kefungsian. Aspek struktur adalah berkaitan integrasi individu dengan rangkaian sokongan keluarga manakala aspek kefungsian merujuk kepada fungsi atau peranan yang diberi atau diperoleh daripada keluarga. Aspek sokongan kefungsian merujuk kepada sifat sokongan keluarga yang diklasifikasikan kepada empat domain utama iaitu sokongan instrumental, sokongan emosi, sokongan maklumat dan integrasi sosial (King, Mattimore, King \& Adams, 1995). Sokongan instrumental merujuk kepada bantuan yang diberikan oleh ahli keluarga dalam melakukan aktiviti fizikal seperti mengemas rumah, penyediaan pengangkutan atau wang manakala sokongan emosi merujuk kepada perasaan seseorang tentang pengalaman yang disukai, dikagumi, dihormati atau disayangi. Sokongan maklumat pula melibatkan penyediaan maklumat semasa individu mengalami tekanan. Integrasi sosial pula merujuk kepada penglibatan individu terhadap kumpulan yang mempunyai kepentingan dan aktiviti bersama (Elkhaldi, 2013).

\section{Sokongan sosial keluarga dengan kemurungan}

Jones dan Logan (2013) menyatakan sokongan sosial keluarga merupakan indikator yang signifikan terhadap kesihatan mental iaitu kemurungan, Individu yang tidak mempunyai hubungan kekeluargaan yang baik dan mempunyai tahap sokongan daripada keluarga yang rendah menunjukkan skor kemurungan yang lebih tinggi. Kajian oleh Ali dan Ahmad (2019) mengenai kemurungan dan bunuh diri dalam kalangan anggota polis di Malaysia menunjukkan terdapat 1 kes pada tahun 2014, 2 kes masing-masing pada tahun 2015, 2017 dan 2018. Konflik yang berlaku di rumah menyebabkan pergaduhan dan penceraian yang mendorong kepada kemurungan kepada anggota polis kerana mereka berasa tidak dihargai oleh pasangan dan anak-anak serta tidak mendapat sokongan.

Secara umumnya, sokongan sosial keluarga, rakan-rakan dan persekitaran mempunyai perkaitan yang signifikan dengan kesihatan fizikal dan psikologi individu (Wang et al., 2010). Schnettler et al. (2013) 
berpendapat bahawa sokongan sosial keluarga memainkan peranan penting terhadap kesihatan mental khususnya kemurungan dan bertindak sebagai penampan dalam menghadapi peristiwa kehidupan yang mendatangkan tekanan. Hal ini dibuktikan juga dalam kajian oleh López-Cepero et al. (2021) yang menunjukkan selepas 16 minggu individu yang mengalami kemurungan menjalankan terapi sokongan sosial keluarga, terdapat penambahbaikan, kemajuan dan peningkatan dalam kemampuan mereka menangani kemurungan. Terapi sokongan keluarga yang diberi adalah dengan mendengar luahan masalah yang dihadapi, memberi galakan dan sokongan penuh kepada ahli keluarga iaitu anggota polis. Kadar penurunan kemurungan yang dialami menunjukkan keberkesanan faktor sokongan sosial daripada keluarga. Dapatan ini disokong oleh kajian Elkhaldi (2013) yang dipetik daripada Alaqra'a (2004) yang turut menunjukkan sokongan sosial ahli keluarga kepada pesakit kemurungan sepanjang proses rawatan dan menyebabkan pesakit bersikap optimistik dan ini membantu proses pemulihan pesakit.

\section{Metod Kajian}

\section{Reka Bentuk Kajian}

Kajian ini menggunakan pendekatan kuantitatif dan reka bentuk yang dipilih adalah korelasi dan deskriptif. Reka bentuk korelasi dipilih kerana kajian ini bertujuan menentukan perkaitan antara pemboleh ubah bersandar iaitu kemurungan dengan pemboleh ubah bebas iaitu sokongan sosial keluarga. Kajian ini memfokuskan kepada anggota polis yang bekerja di Jabatan Siasatan Jenayah Selangor kerana mereka mempunyai skop dan ciri kerja yang menepati objektif kajian iaitu mempunyai risiko tinggi untuk menghadapi tekanan yang boleh menyebabkan kemurungan akibat kerja yang berbahaya. Manakala Selangor dipilih sebagai lokasi kajian kerana berdasarkan statistik PDRM, Selangor merupakan negeri yang mempunyai jenayah indeks tertinggi di Malaysia. Jumlah kes jenayah yang tinggi mendedahkan anggota polis kepada keadaan yang berisiko. Kaedah tinjauan melalui borang soal selidik yang ditadbir sendiri oleh responden kajian telah digunakan bagi proses pengumpulan data. Borang soal selidik digunakan untuk memudahkan proses pengumpulan maklumat daripada responden sama ada dari segi latar belakang (umur, jantina, taraf perkahwinan, bilangan anak dan jumlah tahun pendidikan) mahupun skor bagi setiap skala yang digunakan dalam kajian ini.

Penentuan saiz sampel adalah berdasarkan formula oleh Kerjcie dan Morgan (1970). Hasil pengiraan formula tersebut memberi nilai saiz sampel sebanyak $n=388.94$. Kaedah persampelan yang digunakan dalam kajian ini adalah persampelan rawak secara berlapis dan responden telah dipilih secara rawak. Persetujuan daripada responden untuk terlibat secara sukarela telah diperoleh sebelum pengedaran borang soal selidik dilakukan. Responden turut dijelaskan tentang kerahsiaan maklumat yang diberikan. Pengedaran borang soal selidik dibantu oleh pegawai penghubung di Ibu Pejabat Daerah berkaitan. Jumlah responden sebenar kajian ini adalah seramai 336 orang setelah saringan dibuat dan mana-mana borang soal selidik yang tidak lengkap ditolak. Kajian ini juga telah mematuhi etika penyelidikan dan mendapat kelulusan daripada Jawatankuasa Etika Penyelidikan yang Melibatkan Subjek Manusia Universiti Putra Malaysia (JKEUPM-2019-268).

\section{Pengukuran}

Pemboleh ubah bersandar kajian adalah kemurungan yang diukur dengan menggunakan skala Depression Anxiety Stress Scale (DASS-21) oleh Lovibond \& Lovibond (1995) yang telah diterjemahkan ke Bahasa Melayu oleh Professor Dr Ramli Musa (Pusat Maklumat dan Kajian Kesihatan Mental, Universiti Islam Antarabangsa, Malaysia). Skala ini mengandungi 21 item yang mengukur kemurungan, kegelisahan, dan tekanan individu. Pengukuran adalah dalam bentuk skala likert empat mata iaitu ' 0 = Tidak Diterapkan pada diri saya, ' 1 = Diterapkan kepada saya untuk beberapa peringkat atau beberapa masa', ' 2 = Diterapkan kepada saya untuk sebahagian masa', dan ' 3 $=$ Diterapkan kepada saya dalam kebanyakan masa'. Nilai alfa Cronbach yang dicatatkan adalah 0.80 bagi keseluruhan skala. Nilai alfa Cronbach bagi kemurungan adalah 0.80, kegelisahan adalah 0.72 dan tekanan adalah 0.77 . 
DOI: https://doi.org/10.47405/mjssh.v6i9.1012

Manakala, sokongan sosial keluarga pula diukur dengan menggunakan Family Support Inventory for Workers (FSIW) oleh oleh King, Mattimore, King \& Adams (1995). Skala ini mengandungi 44 item yang mengandugi 2 subskala iaitu sokongan emosi (29 item) dan sokongan instrumental (15 item). Item dalam skala ini mempunyai 5 mata likert iaitu ' $1=$ Sangat Tidak Setuju', ' 2 = Tidak Setuju' ' 3 = Kadang-Kadang Tidak Setuju', ' 4 = Setuju', '5=Sangat Setuju'. Nilai reliabiliti, alfa Cronbach dalam kajian lepas bagi subskala sokongan emosi ialah di antara 0.95 hingga 0.97 manakala sokongan instrumental adalah 0.93 hingga 0.94 .

\section{Analisis Data Kajian}

Kajian data yang diperoleh dianalisis dengan menggunakan program Statistical Package for Social Science (SPSS) Versi 19.0. Statistik deskriptif telah digunakan untuk memperihal ciri personal responden, sokongan sosial keluarga dan kemurungan. Ujian Pekali Korelasi Pearson pula telah digunakan untuk menentukan perkaitan antara sokongan sosial keluarga dengan kemurungan dalam kalangan anggota polis. Manakala, ujian Regresi Berganda pula digunakan untuk menentukan faktor peramal unik bagi kemurungan.

\section{Hasil Kajian}

\section{Ciri Personal Anggota Polis}

Jadual 1 menunjukkan data deskriptif mengenai ciri personal responden iaitu jantina, umur, taraf perkahwinan, bilangan anak dan jumlah tahun pendidikan.

Jadual 1: Ciri Personal Anggota PDRM ( $\mathrm{n}=336)$

\begin{tabular}{lll}
\hline Demografi & Frekuensi $(\mathbf{N})$ & Peratus $\mathbf{( \% )}$ \\
\hline Jantina & & \\
Lelaki & 270 & 67.6 \\
Perempuan & 109 & 32.4 \\
\hline Umur & & \\
19-38 tahun & 203 & 60.4 \\
39-58 tahun & 128 & 38.1 \\
$>38$ tahun & 5 & 1.2 \\
\hline Taraf Perkahwinan & & \\
Berkahwin & 328 & 97.6 \\
Bercerai & 8 & 2.4 \\
\hline Bilangan Anak & & \\
Tiada anak & 35 & 10.4 \\
1-5 orang & 283 & 84.2 \\
6-10 orang & 17 & 5.1 \\
$>10$ orang & 1 & 0.3 \\
\hline Jumlah Tahun Pendidikan & & \\
1-6 tahun (UPSR) & 1 & 0.3 \\
7-9 tahun (PMR/PT3) & 7 & 2.1 \\
10-11 tahun (SPM) & 167 & 49.7 \\
12-14 tahun & 92 & 27.4 \\
(Diploma/Asasi/Matrikulasi) & & \\
15-18 tahun (Sarjana Muda) & 58 & 17.3 \\
19-21 tahun (Sarjana) & 38 & 2.4 \\
22-24 tahun (PHD) & 1 & 0.3 \\
25 tahun ke atas & 2 & 0.6 \\
\hline
\end{tabular}


Berdasarkan analisis tersebut, jumlah responden adalah seramai 336 orang yang terdiri daripada responden lelaki sebanyak 67.6 peratus $(n=227)$ dan responden perempuan sebanyak 32.4 peratus $(\mathrm{n}=109)$. Selain itu, peratusan responden yang berumur 19 hingga 38 tahun adalah sebanyak 60.4 peratus ( $\mathrm{n}=203)$. Peratusan responden berumur antara 39 hingga 58 tahun adalah sebanyak 38.1 peratus $(n=128)$ manakala peratusan responden yang berumur melebihi 58 tahun iaitu 1.2 peratus $(n=5)$.

Majoriti responden adalah mempunyai taraf berkahwin iaitu sebanyak 97.6 peratus $(n=328)$ diikuti dengan responden yang bercerai sebanyak 2.4 peratus $(n=8)$. Kebanyakan responden mempunyai 1 hingga 5 orang anak ( 84.2 peratus, $n=283$ ). Manakala, responden yang tidak mempunyai anak adalah sebanyak 10.4 peratus $(n=35)$, peratusan responden yang mempunyai 6 hingga 10 orang anak sebanyak 5.1 peratus $(n=17)$ dan responden yang melebihi 10 orang anak sebanyak 0.3 peratus $(n=1)$.

Dari aspek jumlah tahun pendidikan, sebanyak 0.3 peratus $(n=1)$ responden mempunyai jumlah tahun pendidikan antara 1 hingga 6 tahun (UPSR). Peratusan responden yang mempunyai jumlah tahun pendidikan sebanyak 7 hingga 9 tahun (PMR/PT3) adalah sebanyak 2.1 peratus $(n=7)$. Hampir separuh daripada responden (49.7 peratus, $\mathrm{n}=167)$ mempunyai jumlah tahun pendidikan antara 10 hingga 11 tahun (SPM) dan diikuti dengan 27.4 peratus $(\mathrm{n}=192)$ responden mempunyai jumlah tahun pendidikan antara 12 hingga 14 tahun (STPM/ Asasi/ Matrikulasi). Sebanyak 17.3 peratus $(n=58)$ responden mempunyai jumlah tahun pendidikan antara 15 hingga 18 tahun (Sarjana Muda) manakala peratusan responden yang mempunyai jumlah tahun pendidikan antara 19 hingga 21 tahun (Sarjana) adalah sebanyak 2.4 peratus $(n=8)$. Peratusan bagi responden yang mempunyai jumlah tahun pendidikan antara 22 hingga 24 tahun $(\mathrm{PhD})$ adalah sebanyak 0.3 peratus $(\mathrm{n}=1)$ dan peratusan responden yang mempunyai jumlah tahun pendidikan sebanyak 25 tahun ke atas adalah sebanyak 0.6 peratus $(n=1)$.

Jadual 2 menunjukkan kebanyakan responden, iaitu sebanyak 72.3 peratus $(n=243)$ melaporkan mempunyai tahap sokongan emosi yang sederhana. Manakala, 12.8 peratus $(n=43)$ responden melaporkan mempunyai tahap sokongan emosi yang tinggi. Hanya 14.9 peratus $(n=50)$ responden yang melaporkan mempunyai tahap sokongan emosi yang rendah. Secara keseluruhan, dapatan kajian ini menunjukkan responden mendapat sokongan emosi daripada keluarga pada tahap sederhana

Jadual 2: Sokongan Emosi (n=336)

\begin{tabular}{lccc}
\hline \multicolumn{1}{c}{ Sokongan Keluarga } & Kekerapan & Peratus (\%) \\
\hline Rendah & 43 & 12.8 & \\
Sederhana & 243 & & 72.3 \\
Tinggi & 50 & 14.9 \\
\hline Jumlah & 336 & 100.0 \\
\hline
\end{tabular}

Jadual 3 menunjukkan kebanyakan responden, iaitu sebanyak 70.8 peratus ( $n=238$ ) melaporkan mempunyai tahap sokongan instrumental yang sederhana. Manakala, 16.4 peratus $(n=55)$ responden melaporkan mempunyai tahap sokongan instrumental yang tinggi. Hanya 12.8 peratus $(n=43)$ responden yang melaporkan mempunyai tahap sokongan instrumental yang rendah. Secara keseluruhan, dapatan kajian ini menunjukkan responden mempunyai sokongan instrumental secara sederhana

Jadual 3: Sokongan Instrumental $(n=336)$

\begin{tabular}{|c|c|c|}
\hline Sokongan Keluarga & Kekerapan & Peratus (\%) \\
\hline Rendah & 43 & 12.8 \\
\hline Sederhana & 238 & 70.8 \\
\hline Tinggi & 55 & 16.4 \\
\hline Jumlah & 336 & 100.0 \\
\hline
\end{tabular}

Jadual 4 menunjukkan lebih separuh daripada responden, iaitu sebanyak 73.2 peratus $(n=246)$ melaporkan mempunyai tahap kemurungan yang normal. Ini diikuti dengan 15.2 peratus $(n=51)$ responden mempunyai tahap kemurungan yang sederhana dan responden yang mempunyai tahap 
kemurungan secara ringan adalah sebanyak 11.3 peratus $(n=38)$. Hanya 0.3 peratus $(n=1)$ responden yang melaporkan mempunyai tahap kemurungan yang teruk. Akhir sekali, tiada responden yang mempunyai tahap kemurungan yang sangat teruk. Data kajian menunjukkan secara keseluruhannya terdapat 90 responden yang mempunyai gejala kemurungan. Walaupun hanya seorang daripada jumlah tersebut yang melaporkan mengalami tahap kemurungan teruk, ini wajar diambil sebagai indikator bahawa kerja kepolisan berhadapan dengan risiko kemurungan. Maka, langkah intervensi awal perlu dirancang oleh PDRM untuk membantu anggota polis menangani penyakit mental ini.

Jadual 4: Kemurungan ( $\mathrm{n}=336)$

\begin{tabular}{lcc}
\hline \multicolumn{1}{c}{ Kemurungan } & Kekerapan & Peratus (\%) \\
\hline Normal (0-9) & 246 & 73.2 \\
Ringan $(10-13)$ & 38 & 11.3 \\
Sederhana (14-20) & 51 & 15.2 \\
Teruk $(21-27)$ & 1 & 0.3 \\
Sangat Teruk $(>28)$ & 0 & 0 \\
\hline Jumlah & 336 & 100.0
\end{tabular}

\section{Perkaitan antara sokongan sosial keluarga (sokongan emosi dan sokongan instruemental) dengan kemurungan dalam kalangan anggota polis}

Objektif kedua kajian ini adalah untuk menentukan perkaitan antara sokongan sosial keluarga (sokongan emosi dan sokongan instrumental) dengan kemurungan dalam kalangan anggota polis. Untuk tujuan tersebut, dua hipotesis kajian dibina seperti dibawah:

Ho 1: Tiada perkaitan yang signifikan antara sokongan emosi dengan kemurungan anggota polis Jabatan Siasatan Jenayah di Selangor.

Ho 2: Tiada perkaitan yang signifikan antara sokongan instrumental dengan kemurungan anggota polis Jabatan Siasatan Jenayah di Selangor.

Perkaitan antara sokongan emosi dengan kemurungan responden telah diukur melalui analisis ujian Pekali Korelasi. Hasil kajian ini menunjukkan bahawa terdapat perkaitan yang signifikan antara sokongan emosi dengan kemurungan kerana nilai $\mathrm{r}=0.296^{* *}$ dan nilai $\mathrm{p}<0.000$ (rujuk Jadual 5). Hasil kajian menunjukkan bahawa terdapat perkaitan yang signifikan antara sokongan emosi dengan kemurungan, nilai $\mathrm{p}$ adalah kurang daripada 0.05. Maka Ho1 ditolak. Ini bermakna sokongan emosi mempengaruhi kemurungan.

Dapatan ini selari dengan dapatan kajian Lincoln dan Chae (2011) iaitu terdapat perkaitan yang negatif dan signifikan antara sokongan emosi dengan kemurungan. Ini bermaksud semakin tinggi sokongan emosi yang diterima semakin rendah tahap kemurungan responden. Sokongan emosi merupakan faktor pelindung yang diterima daripada ahli keluarga. Faktor pelindung ini berfungsi menurunkan tahap kemurungan responden. Sokongan emosi dapat dilihat apabila ahli keluarga (pasangan atau anak-anak) kerap bertanya khabar kepada ahli keluarga yang bekerja, mendengar masalah di tempat kerja dan bimbang terhadap kesejahteraan ahli keluarga yang bekerja (Lincoln \& Chae, 2011). Layanan sebegini menyebabkan responden berasa disayangi dan dijaga.

Jadual 5: Perkaitan sokongan emosi dengan kemurungan anggota polis $(\mathrm{n}=336)$

\begin{tabular}{lcc}
\hline Pemboleh ubah & \multicolumn{2}{c}{ Kemurungan } \\
\hline & $\mathrm{r}$ & $\mathrm{p}$ \\
Sokongan Emosi & $0.296^{* *}$ & 0.000 \\
\hline
\end{tabular}

Nota: $\mathrm{p} \leq 0.05, * * \mathrm{p} \leq 0.01, * * * \mathrm{p} \leq 0.001$ 
DOI: https://doi.org/10.47405/mjssh.v6i9.1012

Ujian Pekali Korelasi Pearson telah digunakan untuk menentukan perkaitan antara sokongan instrumental dengan kemurungan responden. Hasil ujian menunjukkan terdapat perkaitan yang signifikan dan negatif antara sokongan instrumental dengan kemurungan anggota polis kerana nilai $\mathrm{r}=$ $0.343^{* *}$ dan nilai $\mathrm{p}<0.000$ (Jadual 6). Nilai $\mathrm{p}$ yang kurang daripada 0.05 menunjukkan terdapat perkaitan yang signifikan secara statistik antara dua pemboleh ubah yang berkaitan. Oleh itu, Ho 2 ditolak. Ini bermaksud sokongan instrumental mempengaruhi tahap kemurungan anggota polis. Hasil kajian ini konsisten dengan kajian yang menunjukkan bahawa sokongan sosial merupakan faktor penampan yang memberi impak positif iaitu menurunkan tahap kemurungan individu (Fauth, Gerstorf, Ram, \& Malmberg, 2012).

Jadual 6: Perkaitan sokongan instrumental dengan kemurungan anggota polis $(n=336)$

\begin{tabular}{lcc}
\hline Pemboleh ubah & \multicolumn{2}{c}{ Kemurungan } \\
& $\mathrm{r}$ & $\mathrm{p}$ \\
Sokongan Instrumental & $0.343^{* *}$ & 0.000 \\
\hline
\end{tabular}

Nota: $\mathrm{p} \leq 0.05, * * \mathrm{p} \leq 0.01, * * * \mathrm{p} \leq 0.001$

\section{Faktor peramal unik kemurungan dalam kalangan anggota polis}

Objektif ketiga kajian ini adalah untuk menentukan faktor peramal unik yang mempengaruhi kemurungan dalam kalangan anggota polis. Hipotesis kajian yang dibina seperti dibawah:

Ho 3: Regresi koefisien latar belakang anggota polis iaitu sokongan sosial keluarga (sokongan emosi dan sokongan instrumental) adalah sifar apabila disandarkan dengan kemurungan anggota polis Jabatan Siasatan Jenayah di Selangor.

Analisis regresi berganda yang dijalankan berjaya menghasilkan model regresi yang signifikan. Konflik kerja-keluarga merupakan peramal utama (unik) terhadap kemurungan responden. Sebanyak 12 peratus varian $\left(\mathrm{R}^{2}=0.120\right)$ kemurungan dijelaskan oleh sokongan instrumental dengan nilai $\mathrm{F}=$ 23.783 pada aras signifikan $\mathrm{p}<0.00$ (rujuk Jadual 9). Oleh itu, Ho 3 ditolak. Nilai Beta $(\beta)$ menunjukkan faktor yang paling kuat mempengaruhi kemurungan anggota polis adalah faktor sokongan instrumental, nilai $\beta=0.363, p<0.01$ diikuti dengan sokongan emosi dengan nilai $\beta=$ $0.011, \mathrm{p}<0.01$

Penemuan kajian ini bersesuaian dengan kajian lepas yang menegaskan bahawa sokongan instrumental (ahli keluarga membantu menguruskan tugas rumah tangga, menyediakan makanan, dan membeli barang harian untuk keluarga) berjaya mengurangkan beban responden dan kemurungan responden (Parasuraman, 1996).

Jadual 9: Analisis Regrasi Berganda Kemurungan ( $\mathrm{n}=336)$

\begin{tabular}{lccc}
\hline Pemboleh ubah & \multicolumn{3}{c}{ Kemurungan } \\
\hline & B & SE.B & Beta, $\boldsymbol{\beta}$ \\
\hline Sokongan Emosi & -0.003 & 0.032 & -0.011 \\
Sokongan Instrumental & 0.207 & 0.061 & 0.363 \\
$R^{2}$ & & 0.125 & \\
Adjusted $R^{2}$ & & 0.120 & \\
F & & 23.783 & \\
\hline
\end{tabular}

\section{Kesimpulan}

Kemurungan merupakan gangguan perasaan seseorang yang menyebabkan seseorang itu merasa sedih yang berpanjangan, keletihan dan ketiadaan tenaga, cepat marah serta hilang minat dalam aktiviti harian. Kesihatan mental merupakan faktor penting dalam menentukan kesediaan seseorang individu 
menempuh cabaran di tempat kerja dan kehidupan berkeluarga. Kajian ini menyimpulkan bahawa faktor yang mempengaruhi kemurungan adalah sokongan instrumental dan sokongan emosi. Menjalankan tugas kepolisan yang mencabar dan berisiko terutamanya di bahagian siasatan jenayah jelas memerlukan fokus dan komitmen yang tinggi. Sokongan sosial keluarga amat diperlukan bagi membendung kemurungan dalam kalangan anggota polis. Fakta ini disokong oleh Allison et al. (2019) yang mendapati sokongan instrumental merupakan jenis sokongan sosial yang berfungsi dan memberi kesan terhadap penurunan kemurungan. Dengan perkataan lain, sokongan sosial merupakan faktor penampan yang memberi impak terhadap kemurungan dalam kalangan individu (Fauth, Gerstorf, Ram, \& Malmberg, 2012). Isu kesihatan mental seperti kemurungan dalam kalangan anggota polis perlu diberi perhatian dan diambil tindakan yang sewajarnya oleh pihak berautoriti terutamanya PDRM kerana tahap kesihatan mental yang baik amat diperlukan agar anggota polis mampu menjalankan tugas berat melindungi keselamatan awam dan dalam masa yang sama mencapai kebahagiaan hidup berkeluarga. Sebarang perancangan penambahbaikan Dasar Kesihatan Mental dan program intervensi kemurungan perlulah mengambil kira aspek sokongan sosial keluarga kerana sebagaimana yang dijelaskan oleh Teori Ekologi Keluarga (Bubolz \& Sontag, 1993), individu mempengaruhi dan dipengaruhi oleh persekitarannya. Maka, pengalaman atau masalah kemurungan individu akan memberi kesan bukan sahaja kepada kesejahteraan individu berkaitan tetapi juga kepada kesejahteraan ahli keluarga yang lain.

\section{Rujukan}

Argustaitè-Zailskienė, G., Šmigelskas, K., \& Žemaitienė, N. (2020). Traumatic experiences, mental health, social support, and demographics as correlates of alcohol dependence in a sample of Lithuanian police officers. Psychology, Health \& Medicine, 25(4): 396-401.

Ali, L., \& Ahmad, M. (2019). Kajian Bunuh Diri Dalam Kalangan Warga PDRM. Jurnal Integriti PDRM, 1(1), 10-14.

Bubolz, M.M. \& Sontag, M.S. (1993). Human ecology theory. In P.G. Boss, W.J. Doherty, R. LaRossa, W.R. Schumm, \& S.K. Steinmetz (Eds.), Sourcebook of family theories and methods: A contextual approach (pp. 419-448). New York: Plenum Press.

Button, L. A. (2008). Effect of social support and coping strategies on the relationship between health care-related occupational stress and health. Journal of Research in Nursing, 13(6), 498524.doi:10.1177/1744987107087390

Chen, H. C., Chou, F. H., Chen M. C., Su, S. F, Wang, S. Y., Feng, W.W., Chen, P.C., Lai J. Y., Chao, S. S., Yang, S. L., Tsai, T. C., Tsai, K. Y., Lin, K. S., Lee, C. Y., Wu, H. C. (2006).A survey of quality of life and depression for police officers in Kaohsiung, Taiwan. Qual Life Res, 15: 925932. doi: 10.1007/s11136-005-4829-9

Chesla, C. A. (2010) Do Family Interventions Improve Health? Journal of Family Nursing, 16(4): 355-377.doi:10.1177/1074840710383145

Collazo, J. (2020). Adapting Trauma-Focused Cognitive Behavioral Therapy to Treat Complex Trauma in Police Officers. Clinical Social Work Journal, 1-10.

Elkhaldi, A. (2013). The Impact of Family Support on Recovery of Depressed Patients in Gaza Governorates. http://hdl.handle.net/20.500.12358/20903.

Estrada Pineda, C., Herrero Olaizola, J., \& Rodríguez Díaz, F. J. (2012). La red de apoyo en mujeres víctimas de violencia contra la pareja en el estado de Jalisco (México). Universitas Psychologica, $11(2), 523-534$.

Eurofound (2018). Burnout in the Workplace: A Review of Data and Policy Responses in the EU, Publicatios Office of the European Union. Luxembourg.

Fauth, E. B., Gerstorf, D., Ram, N., Malmberg, B. (2012). Changes in depressive symptoms in the context of disablement processes: Role of demographic characteristics, cognitive function, health, and social support. The Journals of Gerontology. Series B, Psychological Sciences and Social Sciences, 67: 167- 177.

Frone, M. R. (2000). Work-family conflict and employee psychiatric disorders: The National Comorbidity Survey. Journal of Applied Psychology, 85(6): 888-895. doi:10.1037/00219010.85.6.888 
Gariepy, Honkaniemi \& Quesnel-Vallee, (2016). Social support and protection from depression: a systematic review of current findings in Western countries. Br J Psychiatry, 209(4): 284-293. doi: 10.1192/bjp.bp.115.169094.

Gouveia, O.M.R., Matos, A.D. and Schouten, M.J. (2016). Social networks and quality of life of elderly persons: a review and critical analysis of literature. Revista Brasileira de Geriatria e Gerontologia, 19(6):1030-1040.

Halif, M. M., Hassan, N., Saini, M. T., \& Athirah, N. (2020). Social Support as Predictor Towards Occupational Stress Among Employees in Major Telecommunication Companies in Malaysia. Malaysian Journal Of Consumer And Family Economics, 24(1).

Hasmizal, H. (2007). Stres Pekerjaan dan Penggunaan Strategi Daya Tindak di Kalangan Anggota Polis di Wilayah Persekutuan Kuala Lumpur dan Putrajaya. Tesis Sarjana. Universtiti Kebangsaan Malaysia.

Hilliard, B. J. (1981). Natural support systems and coping with major life changes. American Journal of Community Psychology, 7, 263-277.

Husain, W. (2014). The levels of depression, anxiety, and stress in police officers. Acad Res Int, 5(4), 458-465.

Husain, W., Faize, F. A. (2018). Depression, Anxiety and Stress of Police Officers in Sensitive and Insensitive Police Stations. Archives of Psychiatry and Behavioral Sciences, 1(2): 26-31.

House, J.S., \& Kahn, R.L. (1985). Measures and Concepts of Social Support. In S. Cohen \& S. L. Syme (Eds.). Social Support \& Health. (pp. 83-108). New York: Academic Press.

Jacobsson, A., Backteman-Erlandson, S., Padyab, M., Egan Sjölander, A., Brulin, C. (2017). Burnout and association with psychosocial work environment among Swedish firefighters. Global Journal of Health Science, 9(5): 214-225.

Jones, C., Logan, J. (2013). Special Issue: Rediscovering Family and Kinship: new directions for social work theory, policy, and practice. Child and Family Social Work, 18(1): 1-4.

Jones, A. P., \& Butler, M. C. (1980). A role transition approach to the stresses of organizationally induced family role disruption. Journal of Marriage and the Family, 367-376.

Katz, M. H., \& Piotrkowski, C. S. (1983). Correlates of Family Role Strain among Employed Black Women. Family Relations, 32(3), 331. doi:10.2307/584610

Komjakraphan, P., Isalamalai, S. A., Boonyasopun, U., \& Schneider, J. K. (2009). Development of the Thai family support scale for elderly parents (TFSS-EP). Pacific Rim International Journal of Nursing Research, 13(2), 118-132.

King, L. A., Mattimore, L. K., King, D. W., \& Adams, G. A. (1995). Family support inventory for workers: A new measure of perceived social support from family members. Journal of Organizational Behavior, 16(3), 235-258.

Lawson, K. J., Rodwell, J. J., \& Noblet, A. J. (2012). Mental health of a police force: estimating prevalence of work-related depression in Australia without a direct national measure. Psychological reports, 110(3), 743-752.

LaRocco, J. M., House, J. S. and French, J. R. P. (1980). Social support, occupational stress, and health. Journal of Health and Social Behavior, 21, 202-218.

Lincoln, K. D., \& Chae, D. H. (2011). Emotional support, negative interaction and major depressive disorder among African Americans and Caribbean Blacks: findings from the National Survey of American Life. Social Psychiatry and Psychiatric Epidemiology, 47(3), 361-372. doi:10.1007/s00127-011-0347-y

López-Cepero Borrego, J., Estrada-Pineda, C., Chan-Gamboa, E. C., \& Fuente-Barrera, A. (2021). Effect of victimization and perceived support on maintenance of dating relationships among college students in Guadalajara, Mexico. Journal of interpersonal violence, 36(5-6), 2182-2198.

Mohamed Sazif Mohamed Subri. (2011). The Stress Effect Towards PDRM Personnel: A Case Study on Health Problems and Job Satisfaction in Kedah. Masters Diss: Universiti Utara Malaysia, Sintok, Kedah.

Parasuraman, S., Greenhaus, J. H., Rabinowitz, S., Bedeian, A. G., \& Mossholder, K. W. (1989). Work and family variables as mediators of the relationship between wives' employment and husbands' well-being. Academy of management Journal, 32(1), 185-201.

Purba, A., \& Demou, E. (2019). The relationship between organisational stressors and mental wellbeing within police officers: a systematic review. BMC Public Health, 19(1), 1286. 
Queirós, C., Passos, F., Bártolo, A., Marques, A. J., da Silva, C. F., \& Pereira, A. (2020). Burnout and stress measurement in police officers: literature review and a study with the operational police stress questionnaire. Front. Psychol., 11-587. https://doi.org/10.3389/fpsyg.2020.00587

Saleh, N., Arshad, R., Ghani, R. A., \& Isa, R. M. (2015). Kualiti Hubungan Penyelia-Pekerja dengan Konflik Kerja-Keluarga: Peranan Tanggapan Sokongan Penyelia sebagai Pengantara. Jurnal Pengurusan (UKM Journal of Management), 45.

Salmah Othman. (2009). Kecerdasan Emosi dan Tekanan Kerja serta Hubungannya dengan Komitmen Kerja Dalam Kalangan Anggota Polis Diraja Malaysia. (Tesis Sarjana). Universiti Utara Malaysia, Sintok, Kedah, Malaysia

Schnettler, B., Miranda, H., Sepu'lveda, J., Denegri, M., Mora, M., Lobos, G., et al. (2013a). Psychometric properties of the satisfaction with food-related life scale: Application in southern Chile. Journal of Nutrition Education and Behavior, 45(5), 443-449

Stice, E., Ragan, J., \& Randall, P. (2004). Prospective Relations between Social Support and Depression: Differential Direction of Effects for Parent and Peer Support? Journal of Abnormal Psychology, 113(1), 155-159. https://doi.org/10.1037/0021-843X.113.1.155

Sheeber, L., Hops, H., Alpert, A., Davis, B., \& Andrews, J. 1997. Family support and conflict: Prospective relations to adolescent depression. Journal of abnormal child psychology, 25(4): 333344.

Tonsing, K., Zimet, G. D., \& Tse, S. (2012). Assessing social support among South Asians: The multidimensional scale of perceived social support. Asian Journal of Psychiatry, 5(2), 164-168. https://doi.org/10.1016/j.ajp.2012.02.012

Wang, Y., Peng, J. (2017). Work-Family Conflict and Depression in Chinese Professional Women: The Mediating Roles of Job Satisfaction and Life Satisfaction. Int J Ment Health Addiction, 15, 394-406. https://doi.org/10.1007/s11469-017-9736-0

Weiss, D. S., Brunet, A., Metzler, T. J., Best, S. R., Fagan, J. A., \& Marmar, C. R. (1999). Critical incident exposure in police officers: frequency, impact, and correlates. International Society of Traumatic Stress Studies.

Wickramasinghe, N. D., Wijesinghe, P. R., Dharmaratne, S. D., \& Agampodi, S. B. (2016). The prevalence and associated factors of depression in policing: a cross sectional study in Sri Lanka. SpringerPlus, 5(1), 1776. https://doi.org/10.1186/s40064-016-3474-9

Zaidi, N. Y. M., \& Raop, N. A. (2019). Faktor-faktor yang mempengaruhi tekanan kerja dalam kalangan anggota polis: Satu kajian di Kem Batalion 9 PGA Kuala Terengganu. Jurnal Sains Sosial: Malaysian Journal of Social Sciences, 2(1), 103-116. 